\title{
SOME EFFECTS OF EXERCISE ON THE URINARY SEDIMENT
}

\author{
By A. M. ROBERTS \\ (From the Department of Medicine, Stanford Medical School, San Francisco, and the Depart- \\ ment of Medicine, University of Southern California School of Medicine, Los Angeles)
}

(Received for publication August 14, 1934)

In the course of investigations into various changes produced in the body and its functions by exercise, several workers have studied the urine. Diminution of volume and increase in concentration were early recognized. The occurrence of proteinuria and certain factors related to its occurrence were shown. The fact that urea excretion is impaired by vigorous activity was demonstrated. De la Camp is said to have been the first to note the occurrence of a general increase in the number of formed elements in the sediment. His observations have been repeated several times.

This report gives the first data which are quantitative and which show time relationships.

\section{METHODS AND MATERIAL}

The urine studied was obtained from a group of thirty-one apparently healthy young male athletes. Specimens produced before, during, and after exercise were examined. The exercise was strenuous: football and handball. The duration of the period of exercise varied from forty minutes to four hours. Several series of specimens from three members of the group were studied; one series from each of the others. A series of specimens consisted of (1) a timed specimen pro- duced in the period before exercise, (2) a timed specimen produced during the period of exercise, and ( 3 ) one or more timed specimens produced after exercise. During the periods before and after exercise the subjects were under conditions of ordinary activity, i.e., up and about their usual school duties. No attempt was made to control fluid intake. Specimens from each subject were collected successively and were examined within two hours.

Determinations were made of the rate of excretion of urine, the specific gravity, the rate of excretion of protein, and the rates of excretion of red blood cells, white blood cells and renal epithelial cells, and casts.

Protein was determined by the method of Shevky and Stafford (10). The formed elements in the sediment were counted by the method devised by Addis (1).

\section{RESULTS}

The rate of excretion of urine varies greatly. Most individuals, however, show a reduction in the rate of production of urine while exercising which, upon cessation of vigorous activity, is followed by a rapid return toward the rate existing

TABLE I

Summary of data for averages shown in figures

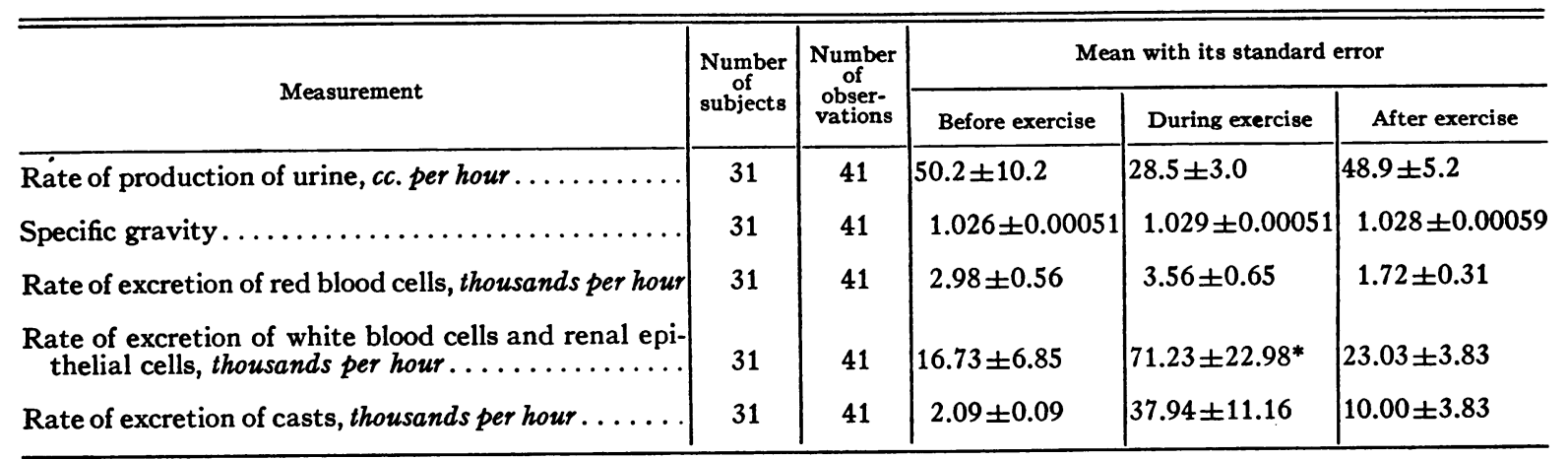

* One widely divergent observation (262) has been excluded. If it is included this figure becomes $75.88 \pm 42.96$ 


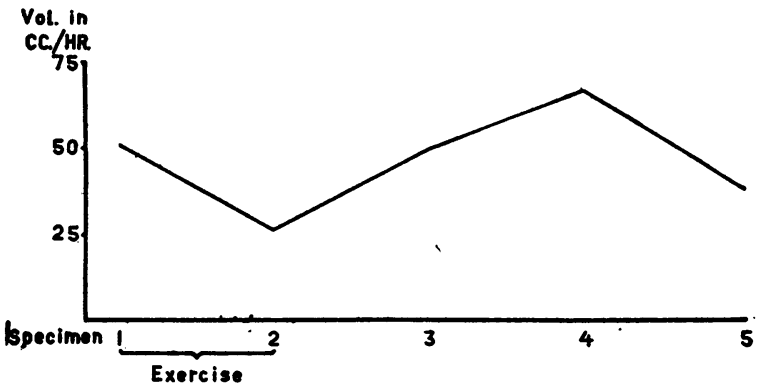

Fig. 1. Effect of Exercise on the Rate of ProducTION OF URINE.

under conditions of ordinary activity. Figure 1 represents the average response of the group.

The specific gravity increased during the period of exercise, Figure 2. Here again the individual

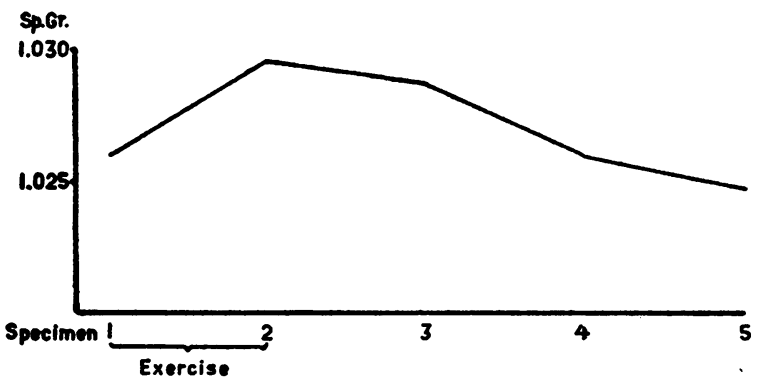

Fig. 2. Effect of Exercise on the Specific Gravity OF THE URINE.

variation was great. As pointed out by Barach (4), in the individual no correlation seems to exist between the change in rate of excretion and the change in specific gravity; a fall in the volume per hour was often associated with a lower specific gravity.

The effect of exercise on the rate of protein excretion, Table II, was inconstant. It varied in different individuals and in the same individual on different occasions. In one subject who had a functional proteinuria, on some occasions the rate of protein excretion increased; on other occasions it decreased.

The number of red blood cells found in the urinary sediment was unaffected by exercise, Figure 3.

In the number of white blood cells and renal epithelial cells appearing in the urine, exercise produced approximately a four-fold increase, Figure 4. In only one instance, however, did the
TABLE II

The rate of excretion of protein in the urine

\begin{tabular}{|c|c|c|c|}
\hline \multirow{2}{*}{$\begin{array}{l}\text { Number of } \\
\text { observations }\end{array}$} & \multicolumn{3}{|c|}{ Rate in mgm. per hour } \\
\hline & Before exercise & During exercise & After exercise \\
\hline $\begin{array}{r}14 \\
1 \\
1 \\
1 \\
1 \\
1 \\
1 \\
1 \\
1 \\
1 \\
1 \\
1 \\
1 \\
2 \\
2 \\
2 \\
1 \\
1 \\
1 \\
1 \\
1 \\
1 \\
1 \\
1 \\
1\end{array}$ & $\begin{array}{l}0 \\
0 \\
0 \\
0 \\
0 \\
0 \\
0 \\
0 \\
0 \\
0.8 \\
1 \\
1.4 \\
2 \\
2 \\
2.4 \\
3 \\
3 \\
4 \\
4 \\
4.4 \\
6 \\
8 \\
11 \\
14 \\
29\end{array}$ & $\begin{array}{c}0 \\
1.7 \\
3 \\
4 \\
4.5 \\
4.8 \\
12 \\
21.8 \\
30 \\
0.4 \\
0 \\
0 \\
2 \\
0 \\
0 \\
2 \\
6 \\
7 \\
3 \\
4 \\
0 \\
2 \\
0 \\
54 \\
140\end{array}$ & $\begin{array}{c}0 \\
0 \\
3 \\
0 \\
0 \\
6 \\
3 \\
0 \\
28.8 \\
0 \\
0 \\
0 \\
2 \\
0 \\
0 \\
0 \\
14 \\
1 \\
1 \\
3 \\
3 \\
4.5 \\
3 \\
3.8 \\
32\end{array}$ \\
\hline
\end{tabular}

R.B.C.

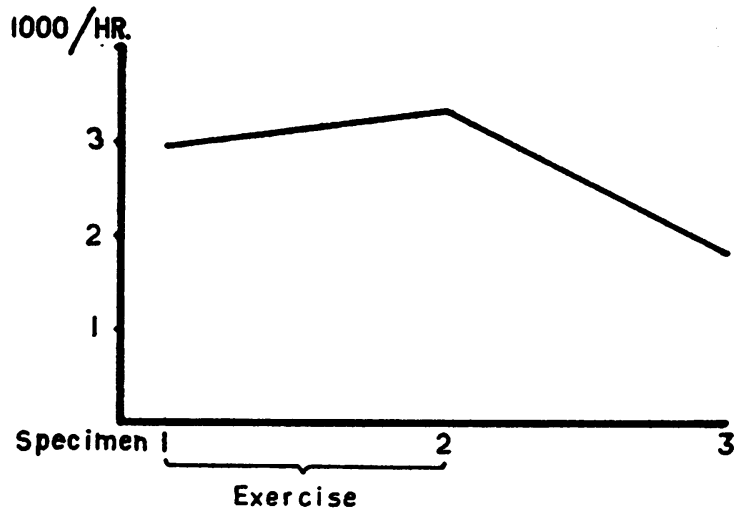

Fig. 3. Effect of Exercise on the Incidence of Red Blood Cells in the Urine.

number of white blood cells and renal epithelial cells exceed the upper limit of normal (Addis). Return to low levels occurred in every instance, usually within three hours.

Exercise produced a great increase in the number of casts found in the urine, Figure 5. In every observation the number of casts excreted during exercise greatly exceeded the upper limit of normal. The casts were largely hyaline, but occasional granular casts were encountered. No 
cellular or blood casts were found. The increase in the number of casts excreted persisted for as long as twelve hours after cessation of activity.

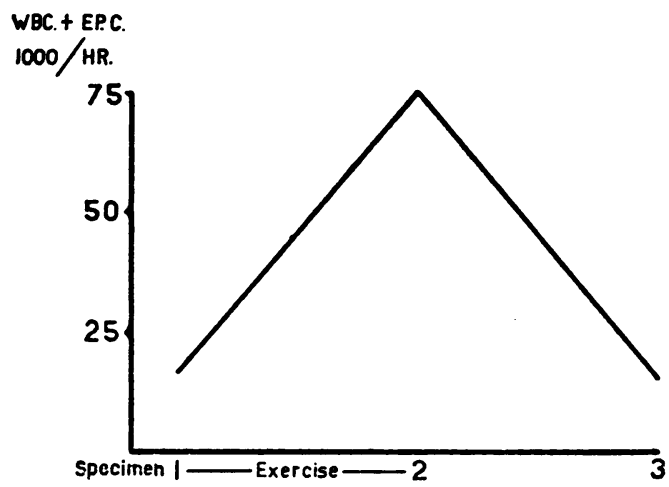

Fig. 4. EfFect of Exercise on the Rate of Excretion of White Blood Cells and Renal Epithelium in Normal Urine.

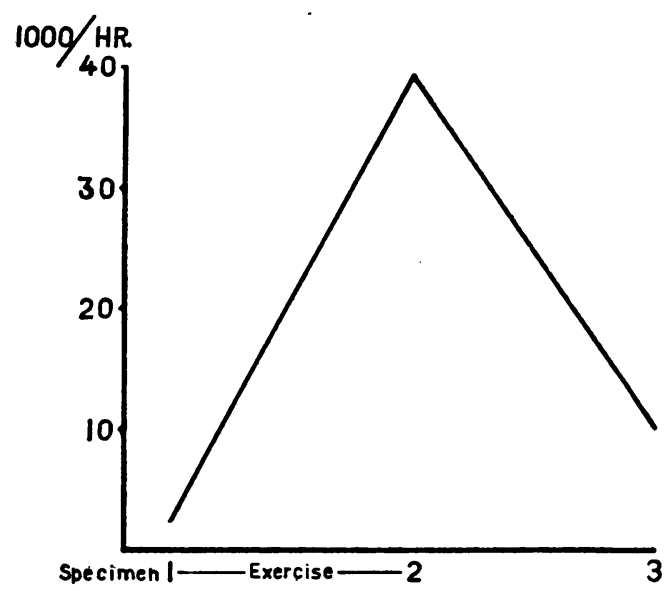

Fig. 5. Effect of Exercise on the Rate of Cast EXCRETION.

\section{CONCLUSION}

Vigorous exercise produces a marked increase in the rate of excretion of hyaline casts, a moderate increase in the rate of excretion of white blood cells and renal epithelial cells but no change in the rate of excretion of red blood cells. Recovery occurs within a few hours after activity is curtailed.

\section{BIBLIOGRAPHY}

1. Addis, Thomas, The number of formed elements in the urinary sediment of normal individuals. J. Clin. Invest., 1928, 2, 409.

2. Addis, Thomas, The effect of some physiological variables on the number of casts, red blood cells and white blood cells and epithelial cells in the urine of normal individuals. J. Clin. Invest., 1925-26, 2, 417.

3. Addis, Thomas, and Drury, D. R., The rate of urea excretion. VII. The effect of various other factors than blood urea concentration on the rate of urea excretion. J. Biol. Chem., 1923, 55, 629.

4. Barach, Joseph H., Physiological and pathological effects of severe exertion (The marathon race) on the circulatory and renal systems. Arch. Int. Med., 1910, 5, 382.

5. Carpentier, G., and Brigaudet, M., Sur certaines modifications du dépôt urinaire au cours du travail musculaire. Bull. Soc. chim. biol., 1927, 9, 580.

6. De la Camp, referred to by Schmidt, F. A., and Kohlrausch, W., Physiology of Exercise. F. A. Davis Co., Philadelphia, 1931.

7. Erlanger, J., and Hooker, D. R., An experimental study of blood pressure and of pulse pressure in man. Johns Hopkins Hosp. Rep., 1904, 12, 357.

8. Hellebrandt, F. A., Studies on albuminuria following exercise. I. Its incidence in women and its relationship to the negative phase in pulse pressure. Am. J. Physiol., 1932, 101, 357.

9. MacKay, Eaton M., Studies of urea excretion. V. The diurnal variation of urea excretion in normal individuals and patients with Bright's disease. J. Clin. Invest., 1928, 6, 505.

10. Shevky, M. C., and Stafford, D. D., A clinical method for the estimation of protein in urine and other body fluids. Arch. Int. Med., 1923, 32, 222.

11. Van Slyke, D. D., Alving, A., and Rose, W. C., Studies of urea excretion. VII. The effects of posture and exercise on urea excretion. J. Clin. Invest., 1932, 11, 1053.

12. Wilson, D. Wright, Long, W. L., Thompson, H. C., and Thurlow, S., Changes in the composition of the urine after muscular exercise. J. Biol. Chem., 1925, 65, 755. 